\title{
Sigi's Response to the Disaster Program: Nutrition, Sanitation, and Food Fulfillment
}

\author{
Hilda Carmitha Panjaitan, ${ }^{1}$ Theresia Pratiwi Elingsetyo Sanubari, ${ }^{1}$ Fiane de Fretes ${ }^{2}$ \\ ${ }^{1}$ Nutrition Study Program, Faculty of Medicine and Health Sciences, Universitas Kristen Satya Wacana, \\ Salatiga, Indonesia, ${ }^{2}$ Nursing Study Program, Faculty of Medicine and Health Sciences, \\ Universitas Kristen Satya Wacana, Salatiga, Indonesia
}

\begin{abstract}
The earthquake occurring in Indonesia caused various problems, especially the decreased degree of human health caused by insufficient food availability. It makes victims of natural disasters need assistance from government programs. One case of a natural disaster in 2018 was an earthquake in Central Sulawesi. Unfortunately, disaster survival has the challenge to continue their living caused by program absences from the government in postdisaster. This study aimed to explore disaster survival's resilience after one year of the earthquake disaster in Sidera village, Sigi regency, in response to government programs, especially nutrition, sanitation, and food fulfillment response. This research used mixed-method approaches with a cross-sectional design. Data collection was done with questionnaires, in-depth interviews, and anthropometric measurements. The study was conducted from February to April 2020 with 30 refugees in the temporary shelter in Sidera village as respondents. The study results found that people still need to initiate countermeasures related to sanitation and fulfillment of food. Government programs in health services produce good conditions related to normal nutritional status at the age of 5 years (40\%), 5-18 years (100\%), and 18 years (41\%). The conclusion is that the government program is not sustainable, which makes the community still need to initiate countermeasures related to sanitation and food fulfillment. The program recommendations are to ensure clean water availability and guide the community to fulfill their food need.
\end{abstract}

Key words: Community resilience, nutrition, post-disaster, program recommendations, sanitation

\section{Tanggapan Sigi terhadap Program Bencana: Gizi, Sanitasi, dan Pemenuhan Pangan}

\begin{abstract}
Abstrak
Gempa bumi yang terjadi di Indonesia menyebabkan berbagai masalah, secara khusus penurunan derajat kesehatan manusia dikarenakan oleh ketersediaan pangan yang tidak tercukupi. Hal tersebut membuat korban bencana alam membutuhkan bantuan dari program pemerintah. Salah satu kasus bencana alam tahun 2018 adalah gempa bumi di Sulawesi Tengah. Namun, hingga pascabencana, korban bencana alam masih tinggal di pengungsian tanpa program. Tujuan penelitian ini adalah mengeksplorasi daya lenting pengungsi pasca-satu tahun bencana gempa bumi di Desa Sidera, Kabupaten Sigi sebagai tanggapan dari program pemerintah khususnya gizi, air bersih, dan pemenuhan pangan. Penelitian ini menggunakan pendekatan mixed-method dengan desain cross-sectional. Teknik pengumpulan data dilakukan melalui pengisian kuesioner, in depth interview, serta pengukuran antropometri. Penelitian dilakukan pada 30 responden yang merupakan pengungsi di hunian sementara (huntara) Desa Sidera. Penelitian dilakukan selama bulan Februari hingga April 2020. Hasil penelitian menemukan bahwa masyarakat masih perlu melakukan inisiasi penanggulangan terkait air bersih dan pemenuhan pangan. Program pemerintah terkait pelayanan kesehatan menghasilkan kondisi yang baik terkait status gizi normal pada usia $\leq 5$ tahun (40\%), 5-18 tahun (100\%), dan $\geq 18$ tahun (41\%). Simpulan dari penelitian ini adalah program pemerintah tidak memiliki keberlanjutan, hal tersebut membuat masyarakat masih perlu melakukan inisiasi penanggulangan terkait air bersih dan pemenuhan pangan. Rekomendasi program yang dapat diberikan adalah ketersediaan air bersih serta pemantauan program dalam membimbing masyarakat agar dapat memenuhi kebutuhan pangan.
\end{abstract}

Kata kunci: Daya lenting masyarakat, gizi, pascabencana, rekomendasi program, sanitasi 


\section{Introduction}

Natural disasters are natural phenomena that threaten human survival, whether earthquakes, floods, or tsunamis, which can cause various risks that threaten human resources' quality, especially health. ${ }^{1}$ In the event of an earthquake, there is a significant risk of injury that requires medical treatment. ${ }^{2}$ When it turns to be a flood or tsunami, it can simply cause damage to the environmental sanitation system and decrease the quality of clean water, so that it will cause various types of diseases such as diarrhea. ${ }^{3}$ Those cases are like what happened in the 2008 Sichuan earthquake and the 2004 Indian Ocean tsunami.4,5

One of the countries classified as having a high risk of natural disasters, especially for the earthquake, is Indonesia. ${ }^{6}$ The earthquake that occurred in Indonesia caused various problems, especially the decreased degree of human health caused by insufficient food availability. It makes victims of natural disasters need assistance from government programs. ${ }^{7,8}$ One case of the natural disasters in 2018 was an earthquake followed by liquefaction and tsunami in Central Sulawesi. This natural disaster was appalling since it was also the first time it occurred in Indonesia..$^{9,10}$ Natural disasters in Central Sulawesi caused various emergencies that affected health, including damage to areas covering residents' houses to agricultural land, especially in the Sigi area, which is the local community's source. ${ }^{11}$ Besides, various health problems have also arisen related to food fulfillment, like diarrhea. ${ }^{12}$ Due to this emergency condition, the local government of Palu made temporary shelters and implemented various programs to deal with the health problems. ${ }^{13}$

Various government programs have been implemented in the Central Sulawesi region, particularly in Sigi regency. ${ }^{14}$ Various evaluations were also carried out by focusing on the achievement of the program being implemented. Unfortunately, the disaster survivors were still living in a temporary shelter without any program until the post-disaster. Therefore this study aimed to explore the resilience of disaster survival after one year of the earthquake in Sidera village, Sigi regency, in response to government programs, especially nutrition, sanitation, and food fulfillment response.

\section{Methods}

This research used a descriptive study with mixed-method approaches having a crosssectional design. This study's population were the disaster survivors in Palu taking refuge in the temporary shelter of Sidera village, Biromaru district, Sigi regency, which was 38 households. The number of respondents in the study was 17 families or as many as 30 people. The sample was selected using the random sampling technique divided into three groups: toddlers, pregnant women, and groups of women and men of all age distribution. Each group met the inclusion criteria, namely: 1) toddlers were included in the pre- and postnatal health care and information center (posyandu) data; 2) covers all age groups, including the elderly; 3) receiving disaster programs from the government. Meanwhile, the exclusion criteria were: respondents still received assistance from their families and did not participate in government disaster programs. The research was conducted from February to April 2020 in a temporary shelter established by aksi cepat tanggap (ACT) in Sidera village.

In collecting the data in the field, first, the observations to monitor the situation and the total number of refugees in the temporary shelter of Sidera village. After having the data, respondents from each family were asked to fill in a questionnaire compiled by researchers based on Ncube et al..$^{15}$ It contained 29 questions about demographics, health, environmental sanitation, and emergency nutrition programs received from the government for pregnant women and other age groups, including the elderly. Also, in-depth interviews were conducted using new interviews related to government programs that have been implemented. The questionnaire was filled in by all respondents, which, especially for infants and toddlers, were represented by parents. Meanwhile, in-depth interviews were conducted with adult respondents (aged 18 years and over). Furthermore, the anthropometric measurement method was carried out on all respondents to determine the Z-score and body mass index (BMI). It served as an indicator for determining respondents' nutritional status relating to the health condition of respondents who depend entirely on government programs. The BMI classification according to the Ministry of Health Republic of Indonesia are severely underweight $<17.0 \mathrm{~kg} / \mathrm{m}^{2}$, underweight $17.0-18.5 \mathrm{~kg} / \mathrm{m}^{2}$, normal $>18.5^{-25.0 ~} \mathrm{~kg} / \mathrm{m}^{2}$, overweight $>25.0-$ $27.0 \mathrm{~kg} / \mathrm{m}^{2}$, and obese $>27.0 \mathrm{~kg} / \mathrm{m}^{2} .{ }^{16}$ While the $\mathrm{Z}$-score category to weight-for-length or height is severely wasted $<-3 \mathrm{SD}$, wasted $-3 \mathrm{SD}$ to 
$<-2 \mathrm{SD}$, normal $-2 \mathrm{SD}$ to $+1 \mathrm{SD}$, possible risk of overweight $>+1 \mathrm{SD}$ to $2 \mathrm{SD}$, overweight $>+2 \mathrm{SD}$ to $+3 \mathrm{SD}$, and obese $>+3 \mathrm{SD}$. Meanwhile, BMI for age are thinness $-3 \mathrm{SD}$ to $<-2 \mathrm{SD}$, normal $-2 \mathrm{SD}$ to $+1 \mathrm{SD}$, overweight $+1 \mathrm{SD}$ to $+2 \mathrm{SD}$, and obese $>+2$ SD. ${ }^{17}$

After the questionnaire data has been collected, it is processed using Microsoft Excel. Meanwhile, the Z-score and BMI results were calculated using the following formula bodyweight = bodyweight weighing according to age; median, standard weight $=$ standard bodyweight according to age; the standard deviation of bodyweight = standard deviation of bodyweight for age.

$$
\begin{aligned}
& \text { BMI }=\frac{\text { Weight }(\text { kilogram })}{\text { Height }(\text { meter })^{2}} \\
& \text { Z-score }=\frac{\text { Bodyweight }- \text { Median standard weight }}{\text { Standard deviation of bodyweight }}
\end{aligned}
$$

The research was conducted during the COVID-19 pandemic so that contact with respondents can still be carried out by paying attention to health protocols. However, this research has weaknesses due to the COVID-19 pandemic in the middle of the research. The data collection was only carried out for families who still live in the temporary shelter while the researcher was out in the field.

Ethical clearance for this study was obtained from the Health Ethics Committee of Faculty of Medicine and Health Sciences in Universitas Kristen Satya Wacana. The issuance of the ethical clearance No. 262/PE/KEPK.UKSW/2020.

\section{Results}

This research succeeded in taking the respondent data of 30 people from temporary shelter in Sidera village. These respondents came from Petobo and Jono Oge village, which were affected by the earthquake and liquefaction. All respondents moved to Sidera village in 2018 and lived in a temporary shelter for more than one year.

This research found that 20 of 30 refugees were dominated by women (Table 1). However, men's fulfillment of needs was carried out, whom most of them (9 of 30) worked as laborers or informal workers. The most age distribution in the temporary shelter was the group over 18 years old, which is 17 of 30 refugees, while the highest level of education was the senior high school.

Based on the results of interviews with all respondents, especially in detail conveyed by the deputy head of the temporary shelter, it was found that the refugees have received assistance from the government while living in a temporary shelter in Sidera Village. Assistance channeled through the health department to provide

Table 1 Respondents Demographic Data in the Sidera Village Temporary

\begin{tabular}{|c|c|}
\hline Descriptions & $\mathbf{n}=\mathbf{3 0}$ \\
\hline \multicolumn{2}{|l|}{ Gender } \\
\hline Male & 10 \\
\hline Female & 20 \\
\hline \multicolumn{2}{|l|}{ Age (years) } \\
\hline$\leq 5$ & 5 \\
\hline $5^{-18}$ & 8 \\
\hline$\geq 18$ & 17 \\
\hline \multicolumn{2}{|l|}{ Level of education } \\
\hline No schooling & 5 \\
\hline Elementary school & 8 \\
\hline Junior high school & 6 \\
\hline Senior high school & 11 \\
\hline \multicolumn{2}{|l|}{ Marital Status } \\
\hline Single & 15 \\
\hline Married & 13 \\
\hline Divorced & 0 \\
\hline Widowed & 2 \\
\hline \multicolumn{2}{|l|}{ Religion } \\
\hline Muslim & 30 \\
\hline \multicolumn{2}{|l|}{ Ethnicity } \\
\hline Palu city & 13 \\
\hline Sidera village & 11 \\
\hline Toraja & 4 \\
\hline South Sulawesi & 1 \\
\hline Solawe & 1 \\
\hline \multicolumn{2}{|l|}{ Language Spoken } \\
\hline Bahasa & 13 \\
\hline Ledo Kaili & 0 \\
\hline Bahasa and Ledo Kaili & 17 \\
\hline \multicolumn{2}{|c|}{$\begin{array}{l}\text { Length of living in a temporary } \\
\text { shelter (month) }\end{array}$} \\
\hline$\leq 1$ & o \\
\hline $1-3$ & 2 \\
\hline $6-12$ & o \\
\hline$\geq 12$ & 28 \\
\hline \multicolumn{2}{|l|}{ Family livelihood } \\
\hline Formal workers & 6 \\
\hline Small trader & 6 \\
\hline Farmer & 3 \\
\hline Labor & 9 \\
\hline Driver & 3 \\
\hline Office guard & 3 \\
\hline
\end{tabular}
Shelter 


\begin{tabular}{lc}
\begin{tabular}{l} 
Table 2 \\
\multicolumn{2}{c}{ Distribution of Nutritional Status } \\
of Children Aged o-5 Years
\end{tabular} \\
\hline Nutritional Status Variable & $\mathbf{n}=\mathbf{5}$ \\
\hline Severely wasted & 0 \\
Wasted & 1 \\
Normal & 2 \\
Risk of overweight possibility & 1 \\
Overweight & 1 \\
Obese & 0 \\
\hline
\end{tabular}

two reservoirs of clean water and provision of pemberian makan bayi dan anak (PMBA) or infant and toddler feeding kitchen equipped with health examinations and counseling for toddlers. The provision of a public kitchen served to process ordinary food for adult groups. This assistance came up because of the difficulty in fulfilling clean water and local food, which causes vomiting and allergies in toddlers. Unfortunately, the assistance provided could not solve all the community's problems, especially water problems due to dry conditions. Finally, the refugees were moved to a temporary shelter established by aksi cepat tanggap (ACT) in Sidera village. In the new residential area, the community received assistance in clean water and provided PMBA kitchens and shared kitchens for two months. However, the time interval for the distribution of this assistance could not be ascertained. Besides, the amount of water given was minimal compared to the number of refugees.

Another problem arose when the PMBA and shared kitchen procurement program stopped after running it for eight months. These conditions eventually encouraged refugees to look for work. The loss of some of their main livelihoods as farmers made most people looked for new jobs as casual daily laborers. Responding to this, an

Table 3 Health History of Respondents in the Temporary Shelter of Sidera

\begin{tabular}{lc}
\hline Medical History & $\mathbf{n}=\mathbf{3 0}$ \\
\hline Do not have certain diseases & 22 \\
Cholesterol & 4 \\
Diabetes mellitus & 1 \\
Gout & 1 \\
Hypertension & 1 \\
Gouty arthritis and cholesterol & 1 \\
\hline
\end{tabular}

Table 4 BMI Frequency Distribution (Over 18 Years)

\begin{tabular}{lc}
\hline BMI $\left(\mathbf{k g} / \mathbf{m}^{\mathbf{2}}\right)$ & $\mathbf{n = 1 7}$ \\
\hline Severely underweight $(<17.0)$ & 0 \\
Underweight $(17.0-18.5)$ & 0 \\
Normal $(18.5-25.0)$ & 7 \\
Overweight $(>25.0-27,0)$ & 4 \\
Obese (>27.0) & 6 \\
\hline
\end{tabular}

NGO called Islamic Relief supported economic improvement activities through empowering women. This empowerment is engaged in processing food from fish, mushrooms, and onions. The activities included providing training for women and providing funds to purchase raw materials. Processed food products were sold in the area of temporary shelters and during exhibition activities in Palu city. Unfortunately, the community admitted that they had difficulty in marketing those preparations. Not fixed and insufficient demand and difficulties in obtaining raw materials were still obstacles to fulfill sales targets.

The economic problems related to food fulfillment ultimately encouraged other people, especially women, to help fulfill the economy by trading on a small scale based on their knowledge. The work as small traders carried out by the community including selling cooked vegetables in the temporary shelter yard, snacks, and accessories through social media.

Apart from the community's problems, respondent's health conditions related to nutritional status at the age of $0-5$ years are shown in Table 2. It can be seen that most status shown (2 of 5 subjects) has normal nutritional status, while the other 1 of 5 has wasted, possible risk of overweight, and overweight.

Respondent's health conditions related to health history are shown in Table 3. It can be seen that most of them (22 of 30) have no history of certain diseases. In comparison, several other respondents have cholesterol as much as 4 of 30, diabetes mellitus, gout, hypertension, gout complications, and cholesterol 1 of 30 , respectively.

All respondents' health conditions related to nutritional status at the age of 5-18 are normal. While the nutritional status at the age over 18 years in Table 4 showed, 7 of 17 have normal 
nutritional status, overweight (4 of 17), and obese (6 of 17).

\section{Discussion}

Based on the interviews, it was found that the condition of the sanitation problem encourages the community to initiate the acquisition of clean water by collecting rainwater. Unfortunately, the absence of directives from the government through the health department has resulted in this initiation harming health due to contaminants in the rainwater consumed. According to Yulistyorini, ${ }^{18}$ although rainwater can be an alternative source of clean water during emergency conditions, such as natural disasters, one must pay attention to the absence of contact with the rainwater surface catchment, rainwater drainage areas, and rainwater storage tanks. It is done to prevent rainwater from carrying contaminants, physically, chemically, and microbiologically. Another problem coming up was the unpredictable weather so that people cannot entirely rely on rainwater.

The resilience that emerges from the community showed that government programs were not sustainable. For example, clean water assistance, which was stopped when people moved to temporary shelters, shared kitchen programs terminated without holding training programs for people to meet their food needs. The provision of programs that ran temporarily without any clear information made people lose trust in the government. It is following research conducted by Surtiari, ${ }^{19}$ which revealed that the lack of information disclosure would trigger public distrust of leaders due to aid issues.

Government programs that only focus on babies and children through the PMBA kitchen and special health services for toddlers have good conditions (Table 2). It can be seen from the majority (40\%) of under-five respondents who have a normal nutritional status, while the other $20 \%$ have wasted, possible risk of overweight, and overweight.

In other age groups, even children and adults, it can be seen that most of them had no history of certain diseases (Table 3). Meanwhile, several other respondents had cholesterol as much as $13 \%$, diabetes mellitus, gout, hypertension, gout complications, and cholesterol 3\%, respectively. Based on the nutritional status data, all groups aged $5-18$ years had a normal nutritional status, and the group aged over 18 years, while most of which (41\%) had normal nutritional status (Table 4). From this data, it can be identified that there were no major health problems in the community, especially those aged over five years. Although the government's focus on the fulfillment of food accompanied by health services specifically aimed at toddlers, the availability of shared kitchens and local health facilities has played a significant role in maintaining children's health conditions to adults.

Unfortunately, people need not only good health conditions to survive but also sanitation and guaranteed food. Article 53 of Law No. 24 of 2007 shows that, apart from health services, other basic needs, such as clean water and sanitation, food, clothing, psychosocial services, and shelter, also need to be fulfilled. ${ }^{20}$ This is because when only health services are fulfilled, diseases that were previously neglected will emerge. In this study, to fulfill water needs, the community took the initiative to collect rainwater that may be contaminated and a potential means of generating, carrying, and spreading diseases, such as cholera and dysentery. ${ }^{21,22}$ On the other hand, the lack of programs in other fields, such as the level of nutritional adequacy, can also decrease endurance. If it is not immediately addressed, it will cause problems in the health sector. ${ }^{23}$

Moreover, although the initial aid provision is following Article 53 of Law No. 24 of 2007 concerning disaster management, the program's continuation was not prepared, especially in the sanitation and food fulfillment program during the post-disaster period..$^{20}$ The programs provided to assist the post-disaster community's economic recovery do not come from the government but NGOs. The program also only provided training related to food processing. The community's condition is not stable yet, and experiencing social pressure due to the formation of new communities. According to Ridwan, ${ }^{24}$ rapid changes in society can bring complexity to problems and challenges.Under the research results conducted by Yulianto, ${ }^{25}$ the negative impact of disaster-affected community groups is damage in the social, economic, and environmental fields, which causes problems to include psychological aspects. In the end, this made the community unable to implement the training system that had been equipped and, in fact, made the community burden even more. 
The government needs to pay attention to the program's instability for the people affected by the disaster. According to Awalia et al. ${ }^{26}$ the government must have the ability to control disasters that occur through disaster response planning and preparation, coordination assistance, reconstruction policies, and overcoming population problems. This refers to Law Number 24 of 2007 concerning disaster management, which emphasizes government efforts including mitigation, placing victims of natural disasters in a safe place, forming a disaster management team, providing counseling, and relocating victims gradually. In its implementation, the government needs to collaborate with related agencies so that disaster management can run well. ${ }^{27}$

This study found that there were some problems related to sanitation and food fulfillment in Sigi regency. Responding to this situation, the program recommendation that can be given is the availability of clean water provided by the government through Municipal Waterworks (PDAM). Dryland conditions should also be a concern in using municipal waterworks. Besides, the government also needs to monitor the programs carried out by nutrition workers from the health department and puskesmas (community health center) in providing direction and guidance to the community. The directive is related to the fulfillment of food to be being able to use vacant land to plant and cultivate freshwater fish. Its implementation still needs to be monitored and evaluated through the health department and the public health care. It is done for follow-up planning and program improvement if there are problems and obstacles in its implementation.

\section{Conclusions}

It can be concluded that the government program is not sustainable, which makes the community still need to initiate countermeasures related to sanitation and fulfillment of food. The program recommendations that can be given are the availability of clean water and guiding the community to fulfill their food.

\section{Conflict of Interest}

All authors stated that there is no conflict of interest in this study.

\section{Acknowledgments}

We want to thank the disaster survivors in the temporary shelter of Sidera village, Sigi regency, for their participation in this study.

\section{References}

1. Husein A, Onasis A. Bahan ajar kesehatan lingkungan: manajemen bencana [Internet]. Jakarta: Kementerian Kesehatan Republik Indonesia;2017 [cited 2020July 15]. Available from: http://bppsdmk.kemkes.go.id/pusdik sdmk/wp-content/uploads/2017/11/Daftarisi-ManajemenBencana_k1_restu.pdf.

2. Handayani SS, Aziz LMUI, Anam ZHF. Penanggulangan trauma pada anak-anak korban gempa bumi. AIMJ. 2019;2(2):81-7.

3. Jusuf MI. Ekologi daerah bencana tsunami dengan gangguan kesehatan. J Sainstek. 2012;6(6):1151.

4. Dong C, Ge P, Ren X, Zhao X, Wang J, Fan $\mathrm{H}$, et al. Growth and anaemia among infants and young children for two years after the Wenchuan earthquake. Asia Pac J Clin Nutr. 2014;23(3):445-51.

5. Badan Nasional Penanggulangan Bencana. Masterplan pengurangan risiko bencana tsunami Internet]. Jakarta: Badan Nasional Penanggulangan Bencana; 2012 [cited 2020 July 15]. Available from: https://www.bnpb. go.id/uploads/migration/pubs/578.pdf.

6. Latief H, Sunendar H, Hadi S, Sengara IW, Rahayu HP. Fenomena tsunami, kajian bahaya, kerentanan, dan risiko serta upaya mitigasinya. In: Zen MT, Abdassah D, Grandis H, Widiyantoro S, Hadi S, Soekarno I, et al., editors. Mengelola risiko bencana di negara maritim Indonesia: bencana kebumian, kelautan, dan atmosferik. Bandung: ITB Research; 2010. p. 157-81.

7. Widayatun, Fatoni Z. Permasalahan kesehatan dalam kondisi bencana: peran petugas kesehatan dan partisipasi maysrakat. JKI. 2013;8(1):37-52.

8. Tondi KM. Deskripsi dampak gempa bumi dan likuifaksi terhadap petani di Desa Jono Oge Kabupaten Sigi Propinsi Sulawesi Tengah. J Agroland. 2019;26(2):148-57.

9. Sassa S, Takagawa T. Liquefied gravity flow-induced tsunami: first evidence and comparison from the 2018 Indonesia Sulawesi earthquake and tsunami disasters. 
Landslides. 2019;16(1):195-200.

10. Valkaniotis S, Ganas A, Tsironi V, Barberopoulou A. A preliminary report on the M7.5 Palu earthquake co-seismic ruptures and landslides using image correlation techniques on optical satellite data [Internet]. Zenodo. 2018 October 19 [cited 2020 July 15]. Available from: http://doi.org/10.5281/ zenodo.1467128.

11. Norfahmi F, Fitri A, Mardiana, Rahayu HSP, Febrianti T, Harfian I, et al. Perubahan penggunaan lahan dan sosial ekonomi rumahtangga petani terdampak gempa bumi, likuifaksi, dan tsunami di Provinsi Sulawesi Tengah. In: Candra AA, Analianasari, Berliana D, Barades E, Kusuma J, editors. Prosiding Seminar Nasional Pengembangan Teknologi Pertanian; 2019 November 7-8; Bandar Lampung. Bandar Lampung: UP Politeknik Negeri Lampung: 2019. p. 55-63.

12. Wiseno B. Masalah kesehatan penyintas gempa dan tsunami di Donggala, Sigi dan Palu, Sulawesi Tengah. JPM. 2019;5(1):32-7.

13. Kementerian Kesehatan Republik Indonesia. Kesiapan menghadapi bencana di Sulawesi Tengah [Internet]. Jakarta: Kementerian Kesehatan Republik Indonesia; 2019 [cited 2020 July 15]. Available from: https://www. kemkes.go.id.

14. Kementerian Kesehatan Republik Indonesia. Data bencana Sulawesi Tengah 2018 [Internet]. Jakarta: Kementerian Kesehatan Republik Indonesia; 2018 [cited 2020 July 15]. Available from: https://www.kemkes. go.id.

15. Ncube A, Kunguma O, Nyahwo M, Manombe S. Nutritional vulnerability: an assessment of the 2010 feeding food programme in Mbire district, Zimbabwe, and its impact on pregnant women. Jamba. 2017;9(1):406.

16. Departemen Kesehatan Republik Indonesia. Petunjuk teknis pemantauan status gizi orang dewasa dengan indeks massa tubuh (IMT). Jakarta: Departemen Kesehatan Republik Indonesia; 2003.
17. Peraturan Menteri Kesehatan Republik Indonesia Nomor 2 Tahun 2020 tentang Standar Antropometri Anak.

18. Yulistyorini A. Permanen air hujan sebagai alternatif pengelolaan sumber daya air di perkotaan. Teknol Kejuruan. 2011;34(1):10514.

19. Surtiari GAK. Pentingnya penanganan pascabencana yang berfokus pada penduduk untuk mewujudkan build back better: pembelajaran dari bencana Palu, Sigi, dan Donggala. Jurnal Kependudukan Indonesia. 2019;14(2):165-84.

20. Undang-Undang Republik Indonesia Nomor 24 Tahun 2007 tentang Penanggulangan Bencana.

21. Purwana R. Manajemen kedaruratan kesehatan lingkungan dalam kejadian bencana. Depok: Rajawali Pers; 2013.

22. El Kharraz J, El-Sadek A, Ghaffaour N, Mino E. Water scarcity and drought in WANA countries. Procedia Eng. 2012;33:14-29.

23. Siswanto, Budisetyawati, Ernawati F. Peran beberapa zat gizi mikro dalam sistem imunitas. Gizi Indones. 2013;36(1):57-64.

24. Ridwan IR. Menyikapi bencana sebagai fenomena sosial terintegrasi. J Geogr GEA. 2016;10(1):33-41.

25. Yulianto A. Strategi adaptasi sosial dan ekonomi masyarakat pasca bencana (studi kasus masyarakat Kampung Trangkil Baru Kelurahan Sukorejo Kecamatan Gunungpati Kota Semarang pasca bencana alam tanah longsor tahun 2014) [undergraduate thesis]. Semarang:UniversitasNegeriSemarang;2015 [cited 2020 July 15]. Available from: https:// lib.unnes.ac.id/27662/1/3401411192.pdf.

26. Awalia VR, Mappamiring, Aksa AN. Peran pemerintah dalam menanggulangi resiko bencana banjir di Kabupaten Kolaka Utara. Otoritas. 2015;5(2):202-13.

27. Heryati S. Peran pemerintah dalam penanggulangan bencana. JP dan KP. 2020;2(2):139-46. 